\title{
Assessment of Selective Reduction Strategies over Northeastern Regions of Ohio Using a Photochemical Grid Model-A Case Study
}

\author{
Jhumoor Biswas ${ }^{1}$, Kevin Crist ${ }^{2 *}$, Saikat Ghosh² \\ ${ }^{1}$ Indian Institute of Social Welfare and Business Management, Kolkata, India \\ ${ }^{2}$ Department of Chemical Engineering, Ohio University, Athens, Ohio, USA \\ Email: ${ }^{\text {cristk@ohio.edu }}$
}

Received 29 October 2014; accepted 10 April 2015; published 21 April 2015

Copyright (C) 2015 by authors and Scientific Research Publishing Inc.

This work is licensed under the Creative Commons Attribution International License (CC BY).

http://creativecommons.org/licenses/by/4.0/

(c) (i) Open Access

\section{Abstract}

This study is primarily focused on Cleveland-Akron-Lorain nonattainment area in northeastern Ohio. The base year 2002 considered in this study witnessed one of the worst cases of ozone pollution in this region with ozone values exceeding previous 8-hour ozone standards of $84 \mathrm{ppb}$. The photochemical modeling system CAMx was applied to compute relative reduction factors, which were used subsequently to scale the base year (2002) values at the ozone monitoring sites to estimate the ozone design values for the year 2009 in Cleveland area for different emissions reduction scenarios. The results disclose that the largest change in the 2009 ozone design values consequent to applying auxiliary emission control strategies is between 1 and $1.5 \mathrm{ppb}$, which still left certain counties in northeastern Ohio unable to demonstrate attainment. The results are important in the development of emission control strategies in today's context with instillation of even more stringent ozone standards and potential future increases in ozone concentrations due to climate change.

\section{Keywords}

8-Hour Ozone, Non-Attainment, Emission Reduction, Relative Reduction Factor, Source Apportionment, Northeastern Regions of Ohio, Photochemical Grid Model

\footnotetext{
${ }^{*}$ Corresponding author.
}

How to cite this paper: Biswas, J., Crist, K. and Ghosh, S. (2015) Assessment of Selective Reduction Strategies over Northeastern Regions of Ohio Using a Photochemical Grid Model-A Case Study. Atmospheric and Climate Sciences, 5, $106-119$. http://dx.doi.org/10.4236/acs.2015.52008 


\section{Introduction}

In the past decade, many of the states in the United States have been actively involved in the development of state implementation plans (SIPS) for the attainment of National Ambient Air Quality Standards for ozone. The United States Environmental Protection Agency (USEPA) has revised the 8-hour ozone standards to more stringent values based on stricter health considerations. The shift to the stricter 8-hr standards has major implications on the ozone non-attainment issue. Since time and spatial scales are inherently connected in the ozone process [1], the more exacting 8-hour ozone standards will lead to a more widespread non-attainment problem [2]. On the basis of the stricter ozone standards of $75 \mathrm{ppb}$ set in 2008, USEPA designated 192 non-attainment counties. [3]. Amongst them, there are currently 19 counties in the state of Ohio inclusive of eight counties in northeast of Ohio which do not meet 2008 8-hour ozone standards. USEPA has issued a draft modeling guidance [4], which necessitates the development of a State Implementation Plan (SIP) that requires a demonstration by the non-attainment regions that the projected future ozone 8-hour ozone concentrations will meet compliance standards. For basic non-attainment areas in Ohio, the state agency responsible for undertaking tasks to uphold air quality standards in the state of Ohio, the Ohio Environmental Protection Agency (Ohio EPA) maintains that a reasonable level of new controls will be needed to reach attainment within the dates specified by USEPA. Although there have been substantial reductions in ozone concentrations in Midwest [5], the enormous challenge lies in moderate non-attainment areas, like northeast Ohio. A design value is the calculated concentration used to determine if a monitor is measuring air quality in attainment of a standard. Under EPA guidelines, the design values for observed 8-hour ozone concentrations established at each ozone monitoring site are equal to the average of the fourth highest annual daily maximum 8-hour values for the most recent three years at that site. The three-year average provides a method for reducing the reliance of the ozone design values on variable short-term meteorological effects [6]. Despite the modeled 8-hour ozone attainment demonstration, USEPA guidance recommends using the average of three consecutive design values.

The ozone attainment demonstration is usually accomplished by using air quality photochemical models. Several studies in the past have illustrated the importance of these models in making regulatory decisions [7] [8]. Following the guiding principles laid down by EPA [9], the modeling results are applied in a relative way to scale the current observed 8-hour ozone design values at each observational site to project ozone design values for future years. These are then measured against ambient air quality standards. An area is considered in attainment of the 8-hour ozone standards if the projected modeled future year design value of 8-hour ozone is less than the ozone standard. The model-based relative reduction factors (ratios of model simulated high ozone concentrations of the base year to that of the future year (RRFs)) are multiplied by current ozone design values to estimate the design values of ozone for the future year for each monitor in the non attainment region. RRFs are currently generated for model cells corresponding to monitor locations using the average ratio between base year and future base year concentrations for days starting with modeled concentrations above 85 ppb throughout the model simulation [10].

The photochemical models are evaluated first to determine if an acceptable base case performance in the selected region has been achieved. They are then applied to assess control strategies and to demonstrate attainment [11]. Instead of using air-quality models only as a final check of an overall strategy, the air quality modelers and policy developers can collaborate early in the SIP process to estimate the responsiveness of the ambient ozone concentrations to various emission reductions. Sensitivity analyses can be used to identify and prioritize certain control measures and facilitate the search for additional measures, if the initial strategy proves to be insufficient. The projected 2009 emissions inventory in the case study incorporated emission reductions associated with implementation of power plant emissions' reductions due to the EPA Clean Air Interstate Rule (CAIR), federally mandated industrial controls such as maximum achievable control technology (MACT) standards for point source emissions, and turnover of the motor vehicle fleet to progressively cleaner vehicles for mobile source emissions.

The principal objective of this study is to attempt to evaluate the reasons for ozone non-attainment in the Cleveland region and endeavor to develop effective control strategies to combat it. In this study, emissions from different emission source categories for the northeast Ohio region were further modified in 2009 to perform additional emission sensitivity model runs, and the impacts of these selective emission sensitivity runs were investigated to demonstrate if the region could demonstrate attainment with these supplementary measures. The pho- 
tochemical modeling system CAMx has been used to assess RRFs from the base and all control case modeling runs for the entire Ohio Region with special focus on the Cleveland region. Since the RRFs are based on modeled values, there can be uncertainties associated with the future year ozone design values [6] [12] based on the modeling system used for the demonstration. The results indicate the relative effectiveness of emission control strategies that can be utilized in today's scenario in northeast Ohio to gain attainment of ozone standards. The worst case scenario explored in this study can be useful in development of effectual emission control strategies in context of ozone increments due to potential climate perturbations [13].

\section{Study Area}

Cleveland, Akron, and Lorain located in northeastern Ohio are influenced by air circulations from lakes with poor air quality associated with weak lake breeze that can lead to stagnation and poor dispersion. Transport of regional pollution by southern winds can also impact air quality episodes. The focus in this study is to adjudge the efficacy of emissions controls, which can lead to meeting of ozone standards despite meteorological uncertainties allied with northeasten Ohio.

\section{Model Description}

For attainment demonstration purpose the Comprehensive Model for Air Quality (CAMx) with extensions version 4.3 [14], the Emissions Processing Model [15] and the mesoscale meteorological model MM5 were applied to the Eastern United States for the base year 2002 and the future base year 2009 with the projected emission cuts incorporated for the future base case scenario. CAMx is a three-dimensional photochemical grid-based model with the Carbon Bond Mechanism, version IV. The CAMx model is being used for regulatory purposes by several states. The meteorological inputs to the photochemical model were provided by the non-hydrostatic Penn State/NCAR Mesoscale model (MM5), Version 3 [16]. All models were applied with a Lambert projection centered at $(-97,40)$ and true latitudes at 33 and 45.The base case model simulations were performed from June 14 to August 13, 2002 in a non-nested mode with a horizontal grid cell dimension of $36 \mathrm{~km}$ in a domain consisting of major portions of the continental United States (Figure 1).

The longer-term simulation takes better care of regional transport and minimizes influence from initial concentrations [17]. The vertical structure in the model consisted of 14 layers from the surface up through $4 \mathrm{~km}$. The

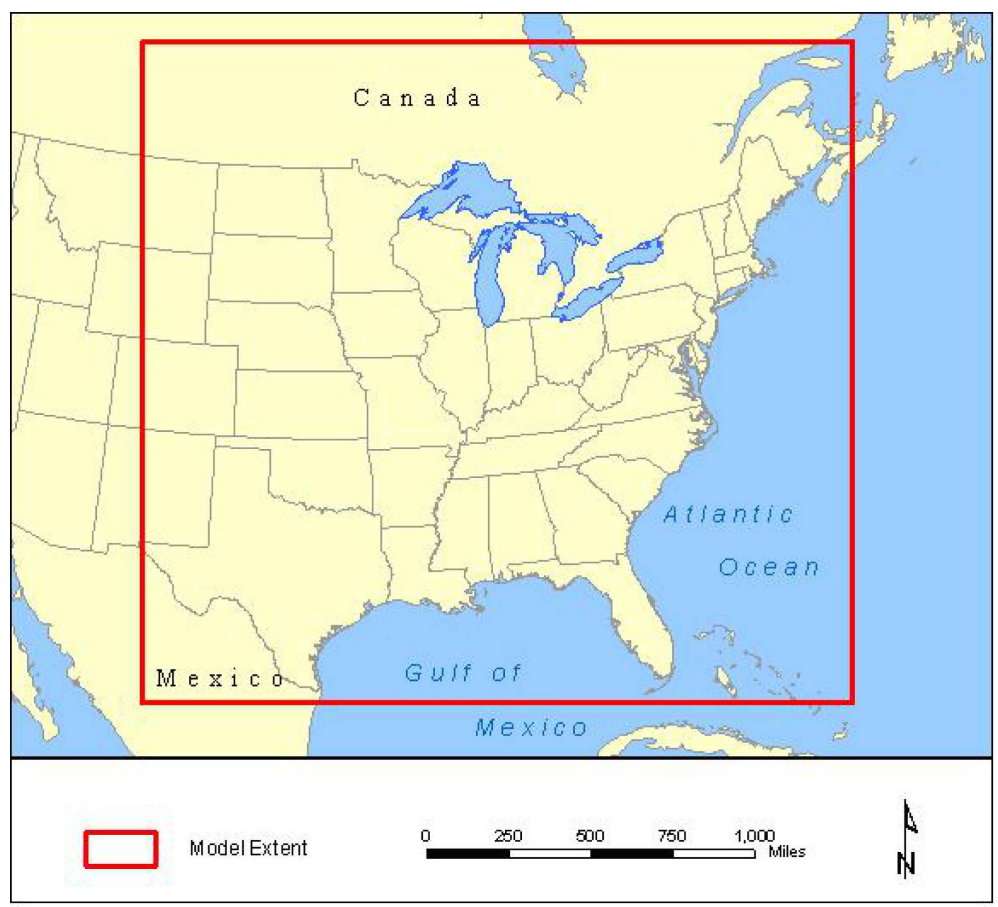

Figure 1. Modeling domain. 
2009 emissions future run was also conducted for the same time period and over the same modeling domain. The initial and boundary conditions used in the model runs as well as more comprehensive details of the set up of the photochemical model can be found in [17]. EMS configurations as well as physical parameterization schemes utilized in the MM5 model have been presented in [17].

\section{Results}

\subsection{Evaluation of Model Performance}

During SIP development, once the base case simulation meets performance criteria specified by regulatory agency such as the EPA the photochemical model is then rerun with scenarios representing emissions reductions from hypothetical controls. In this study the model performance validation for the base year 2002 has been conducted based on 8-hour daily ozone maximum values from observational (monitored) data and modeled simulations

Since ozone is a regional-based problem [18], to obtain a perspective on the regional performance of the modeling system, two statistical metrics [19] were applied for the entire summer season over all possible observational sites (i.e. sampling through space and time). This analysis was based on the measured and simulated values of 8-hour ozone concentrations for more than 600 sites (Figure 2) located in the Eastern United States. The two performance metrics used for model evaluation purposes were 1) unpaired peak accuracy and 2) the mean normalized gross error, both expressed as a percentage. The former provides a measure of the model's ability to capture the daily peak ozone concentrations and the latter is a measure of the model's overall performance [20]. According to [21], both sets of calculations were performed on the hourly measured concentrations greater than or equal to $60 \mathrm{ppb}$. The $60 \mathrm{ppb}$ minimum threshold level excludes prediction-observation pairs that are not of direct regulatory importance since the 8-hour ozone attainment test only applies to days with high ambient concentrations, which are defined as days with greater than $70 \mathrm{ppb}$ of 8-hour ozone [17].

The unpaired peak accuracy is defined as

$$
\frac{100 \times\left(C_{o}-C_{e}\right)}{C_{o}}
$$

where $C_{o}$ and $C_{e}$ are measured and modeled 8-hour averaged peak ozone concentrations respectively. The mean

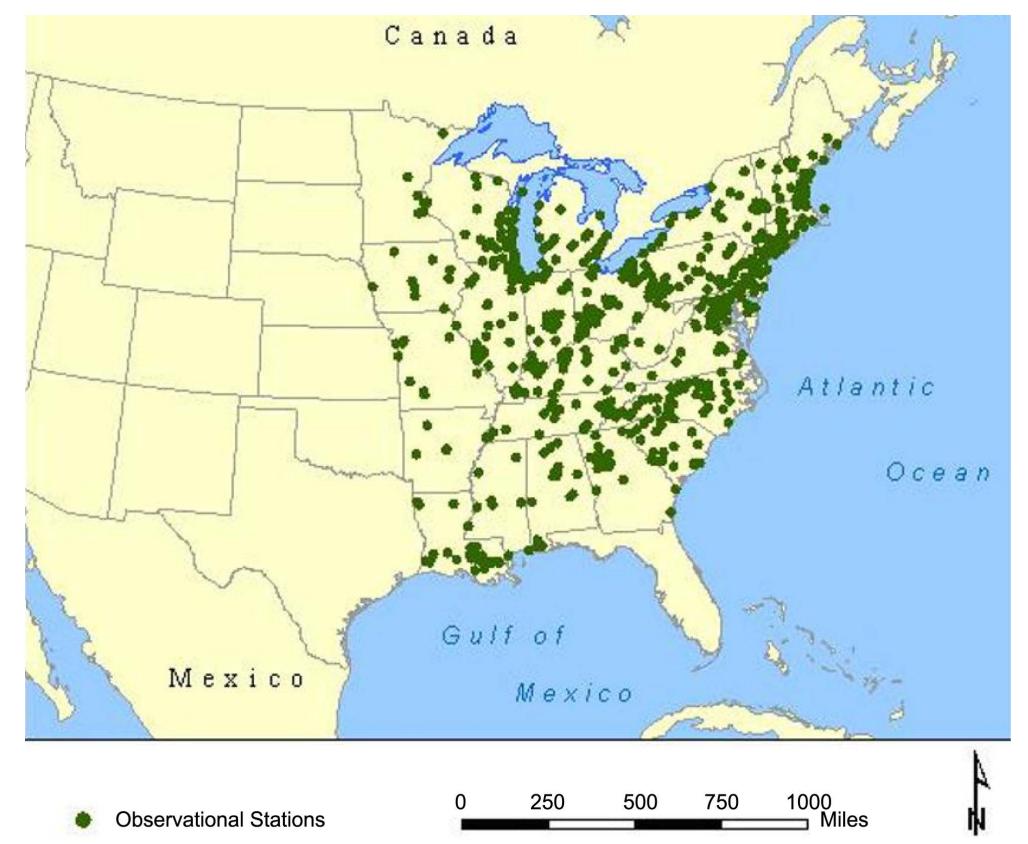

Figure 2. Location of ozone monitoring sites in model subdomain for which performance statistics were computed. 
normalized gross error is given by

$$
\frac{1}{N} \times \sum_{i=1}^{N}\left[\frac{\left(C_{o}\left(x_{i}, t\right)-C_{e}\left(x_{i}, t\right)\right)}{C_{o}\left(x_{i}, t\right)}\right]
$$

where $C_{o}\left(x_{i}, t\right)$ and $C_{e}\left(x_{i}, t\right)$ are measured and modeled concentrations respectively at location $i$ at any given time $t . N$ is the number of pairs of observations and corresponding model simulations.

As seen in Table 1, the model performance for ozone episode days for the months of June, July, and August using both of the performance statistics is well within EPA's criteria for an acceptable model performance [22].

To gauge the model performance over the entire time period of simulation for the state of Ohio where this study is based the scatter plots of 8-hour averaged daily peak ozone concentrations from the 2002 modeling simulations were plotted against the corresponding monitoring data from the entire Ohio region (figure not shown). It was found that although the model over-predicted ozone values with respect to observations in the Ohio region, nevertheless a strong correlation existed between the modeled and monitored data sets. The correlation coefficient for the 8-hour daily peak ozone concentrations for the entire Ohio region was found to be 0.67. A more complete in-depth evaluation of the CAMx model performance for the base year 2002 can be obtained from [17].

\subsection{Attainment Demonstration in the Ohio Region}

The modeling is said to "demonstrate attainment" when modeling results indicate that planned controls will re duce ozone concentrations to below the standard if the meteorological conditions during the simulated time period are experienced again. The EPA draft modeling guidance [23] was used for the attainment demonstration in northeast Ohio. The first step in this process involved calculating the 8-hour averaged ozone design values. These design values were computed from the EPA's Aerometric Information Retrieval System (AIRs) data set for each ozone-monitoring site in the state of Ohio (Table 2). The monitors located in the Cleveland region are presented in Figure 3. The evaluation was especially focused on the 8 county regions, namely, Ashtabula, Cuyahoga, Geauga, Lake, Lorain, Medina, Portage and Summit in northeast Ohio. The second step in the attainment demonstration was to determine relative reduction factors (RRFs) from the model simulations (2002 and 2009). Model estimates are used in a "relative" rather than "absolute" sense. That is, we take the ratio of the model's future to current (baseline) predictions at ozone monitors. We call these ratios, relative reduction factors (RRF). Future ozone concentrations are estimated at existing monitoring sites by multiplying a modeled RRF at locations "near" each monitor by the observation-based, monitor-specific, "baseline" ozone design value. RRFs are calculated for those locations where the monitoring site has a current design value above $75 \mathrm{ppb}$. All the ozone monitors in the selected region (Figure 3) satisfy this criterion. In calculating the RRFs, the first step is to determine the daily maximum 8-hr $\mathrm{O}_{3}$ model simulated ozone concentrations from grid cells that are reckoned determined to be "near" the monitor. For the grid resolution of $12 \mathrm{~km}$ the grid cell in which the monitor was located and the surrounding

Table 1. Unpaired peak accuracy and absolute mean gross error expressed in percent for each day of high 8-hour average ozone concentrations simulated for the year 2002 by MM5/CAMx for the Eastern United States.

\begin{tabular}{ccc}
\hline 6 & Unpaired Peak Accuracy & Absolute Mean Gross Error \\
\hline June 21 & 12.8 & 14.0 \\
June 22 & -2.5 & 14.0 \\
June 23 & 9.6 & 12.1 \\
July 14 & 3.7 & 14.1 \\
July 15 & 7.2 & 16.7 \\
July 16 & -0.5 & 16.5 \\
August 10 & 10.9 & 12.3 \\
August 11 & 7.6 & 4.1 \\
\hline
\end{tabular}




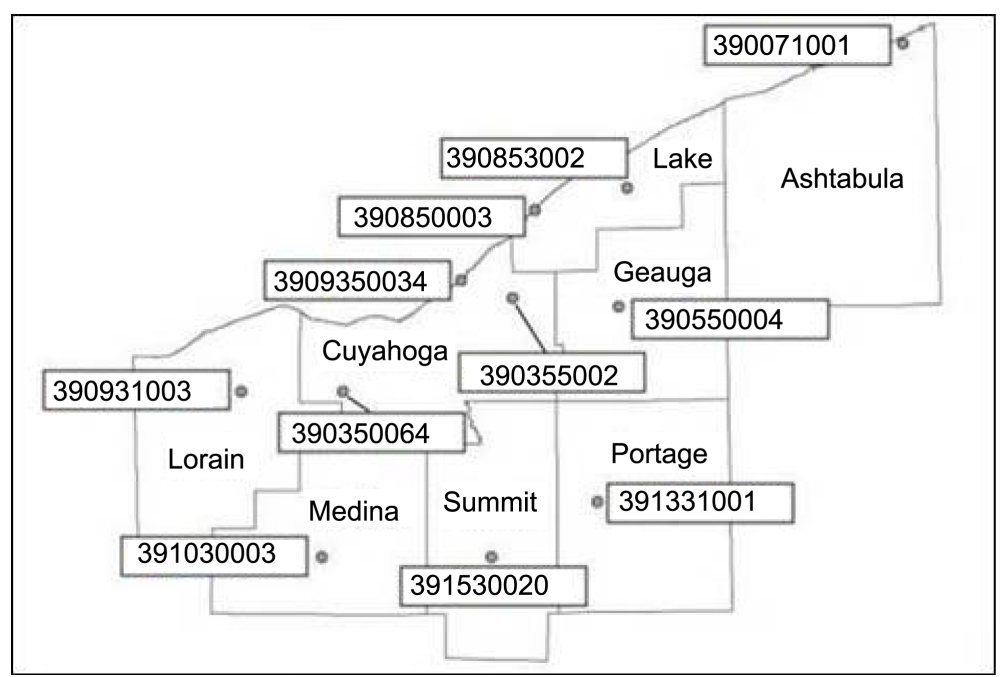

Figure 3. Location of ozone monitors selected for design values in the Cleveland metropolitan area.

Table 2. RRF-scaled 8-hr average ozone values for the 2009 base case and Scenarios 1, 2, 3 \& 4.

\begin{tabular}{|c|c|c|c|c|c|c|c|}
\hline Counties & Station ID & $\begin{array}{c}\text { Modeled Ozone } \\
\text { Values } \\
2009 \\
\text { Base Case }\end{array}$ & $\begin{array}{l}\text { Number of Days } \\
\text { Used for } \\
\text { Calculation of } \\
\text { RRFs }\end{array}$ & $\begin{array}{c}\text { Modeled Ozone } \\
\text { Values } \\
\text { (Scenario 1) }\end{array}$ & $\begin{array}{c}\text { Modeled Ozone } \\
\text { Values } \\
\text { (Scenario 2) }\end{array}$ & $\begin{array}{c}\text { Modeled Ozone } \\
\text { Values } \\
\text { (Scenario 3) }\end{array}$ & $\begin{array}{c}\text { Modeled Ozone } \\
\text { Values } \\
\text { (Scenario 4) }\end{array}$ \\
\hline Cuyahoga & 390350064 & 81 & 35 & 82 & 82 & 82 & 81 \\
\hline Cuyahoga & 390355002 & 86 & 30 & 86 & 86 & 78 & 74 \\
\hline Lake & 390850003 & 91 & 37 & 91 & 91 & 85. & 81 \\
\hline Lake & 390853002 & 76 & 34 & 76 & 76 & 91 & 90 \\
\hline Ashtabula & 390071001 & 89 & 34 & 88 & 88 & 76 & 75 \\
\hline Geauga & 390550004 & 94 & 35 & 94 & 94 & 88 & 87 \\
\hline Portage & 391331001 & 85 & 40 & 85 & 85 & 84 & 83 \\
\hline Summit & 391530020 & 90 & 36 & 90 & 90 & 85 & 84 \\
\hline Medina & 391030003 & 81 & 38 & 81 & 81 & 81 & 80 \\
\hline Lorain & 390930017 & 86 & 35 & 86 & 86 & 85 & 84 \\
\hline
\end{tabular}

grid cells were picked out using the method of nearest 9 cell location. The grid cell in which the daily maximum occurs could differ between the base case and the future case. The RRFs for each of these sites are listed in Table 2 and are defined as the ratio of the maximum daily 8-hour average ozone level for the future case and the base case averaged over the entire simulation for each monitor. For the base case model simulations, days on which the maximum 8-hour average ozone level was less than $70 \mathrm{ppb}$ were not included in this calculation [23]. Therefore, although the time period of the modeling simulations is nearly 60 days (excluding the spin off period of the model) the number of actual days used to calculate the RRFs were significantly less since low ozone concentrations were predicted near the ozone monitors for several days. The longer time period of seasonal simulation used in this study thus ensured sufficient number of averaging days for computation of stable RRF calculations which are sometimes not possible in case of an ozone episode when only a few days are available for the averaging [12].

The final step in the process was to calculate the ozone design value for the future case (2009). The draft guidance suggests the use of these RRFs in the estimation of the future design value at each of the monitors based on the current ozone design value. The future case ozone design value was determined by multiplying the design value 
(defined above) for each monitoring site by the RRFs computed for that location. These values are listed in Table 2. As can be seen from the table the ozone design values at some of the monitoring sites in the study region were not reduced below the preceding ozone standard of $85 \mathrm{ppb}$ indicating that additional controls were necessary to demonstrate attainment in the Cleveland-Akron-Lorain moderate nonattainment area.

\subsection{Implications of Spatial Analysis of RRFs for the Ohio Region}

A spatial analysis of relative reduction factors was carried out to obtain a perception of the spatial variability of the RRFs for the entire Ohio region rather than only in the modeling domain corresponding to the selected monitors. For this analysis following [12] each grid cell was considered a "pseudo monitor" in the modeling domain. The RRF for each of the grid cells was then calculated following the previous procedure. This type of map can also help to illustrate the effects of emission controls in different parts of the domain in comparison to the selected region. Figure 4 displays the results of the analysis. As can be seen from the map the general values of the relative reduction factors in the Ohio region are between 0.85 and 0.92 . However in the urban regions of Cleveland, Cincinnati and Toledo the values are higher although the Cleveland region does not have significantly higher values than these other urban regions. We can conclude that the ozone reduction in these urban regions is lower with anticipated emission controls when compared to the rest of Ohio. This is further reinforced in the next figure (Figure 5) which depicts actual ozone reductions in the Ohio region. Ozone reductions for the future 2009 base case scenario (per the EPA guidance document) is defined as

$$
[100 \% \times(1-R R F)]
$$

Again Cleveland shows lower ozone reduction 5\% - 8\% of 8-hour averaged ozone concentrations from the base case but not noticeably lower than the other urban regions specified earlier. This can be accredited to the non-linear complex chemistry of ozone formation from its precursors. This phenomenon is especially pronounced in the urban regions which consist of abundantly available $\mathrm{NO}_{\mathrm{x}}$ and $\mathrm{VOC}$ concentrations to sustain ozone

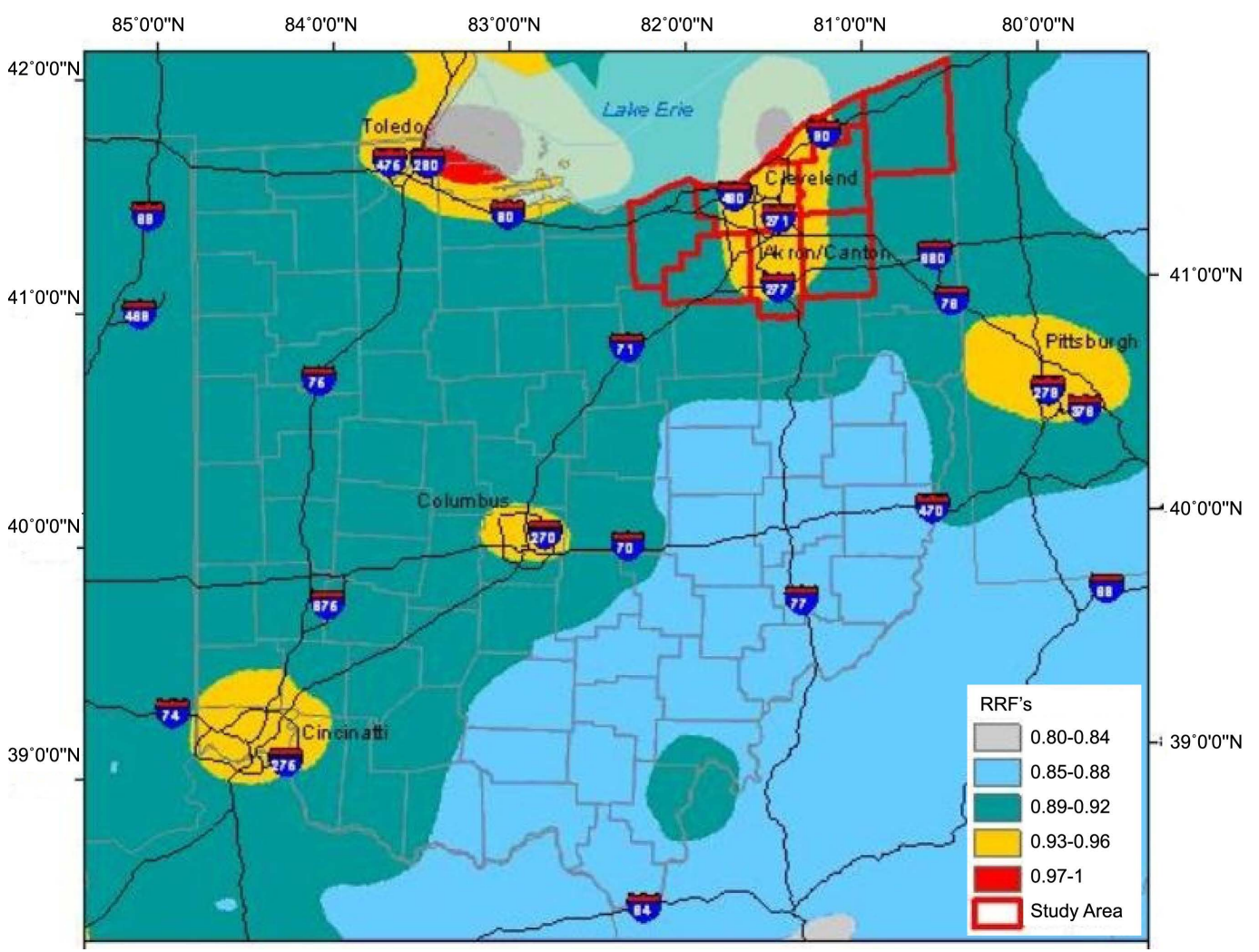

Figure 4. Spatial distribution of the relative reduction of the Ohio region based on 2010 emission reduction scenario. 


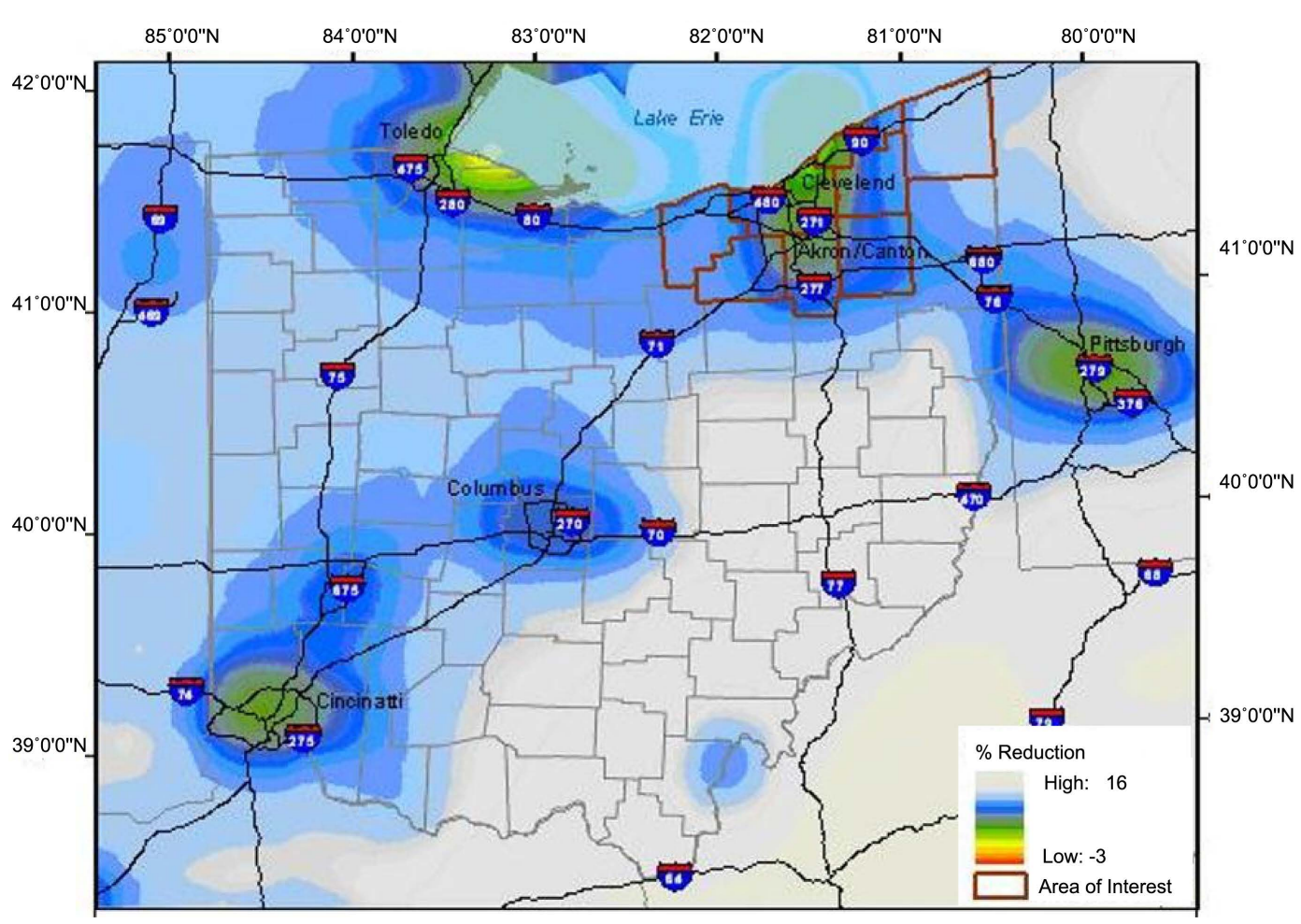

Figure 5. Spatial distribution of ozone reductions in percent based of RRFs for the Ohio region.

production. The VOC limitation and $\mathrm{NO}_{\mathrm{x}}$ limitation characteristics of an air parcel vary dynamically with transport, dispersion, dilution and photochemical aging [24]. Therefore the reduction of precursor emissions does not translate automatically into a linear decrease of model simulated ozone concentrations [25] in urban regions. Figure 6 depicts the number of days used in the RRF calculation used in the Ohio region. It should be noted those regions of Ohio (South east Ohio) which indicate the largest benefits from the VOC and $\mathrm{NO}_{\mathrm{x}}$ reductions also have larger number of high ozone days (ozone concentrations greater than $70 \mathrm{pbb}$ ) which were used in the calculation (approximately 40 - 45 days). The influence of meteorological conditions on ozone exceedances is well-known [26]. Hence the larger number of exceedances in the Cleveland area may also arise as a combination of transport of ozone from upwind areas due to prevailing wind directions on the days of ozone exceedances and in-situ local emissions. A comprehensive analysis of impact of meteorology on the 8-hour ozone exceedances is beyond the scope of this paper.

\subsection{Source Apportionment in the Cleveland Region}

In order to develop successful emission reduction strategies it important to explore further and quantify future relative source contributions of emissions from various regions to the Cleveland counties. It is crucial to identify the overall importance of each of the emission sources both locally generated and regionally transported towards ozone formation in this region. The source apportionment studies would help to examine the effectiveness of potential control strategies.

The Ozone Source Apportionment Technology is a well tested scheme [27] [28] and has been implemented in photochemical air quality model CAMx to estimate the contributions of emissions from multiple source regions and multiple precursor species to ozone concentrations at downwind receptors in a single model simulation. A detailed account of the ozone apportionment technology can be obtained in the user's guide to the CAMx model. In this study OSAT was used to look at the relative contribution of emissions at each monitoring site in the selected regions in northeast Ohio to evaluate the important sources contributing to the problem and to understand the nature of the sources whether they are local or regional. Figure 7 exhibits the results of source apportionment results in the Cleveland territory for base case year 2009 in the selected counties of Cleveland region namely Cuyahoga, Geauga, Lake and Summit which remain in moderate non-attainment. The scenario evaluated 
here is the future case scenario which includes the book controls and CAIR. Figure 7 reveals that the most important source contributors towards ozone concentrations in the region are the mobile sources $(20-28)$ ppb followed by elevated point sources (approximately $12 \mathrm{ppb}$ ) and non-road sources ( 8 - 13) ppb.

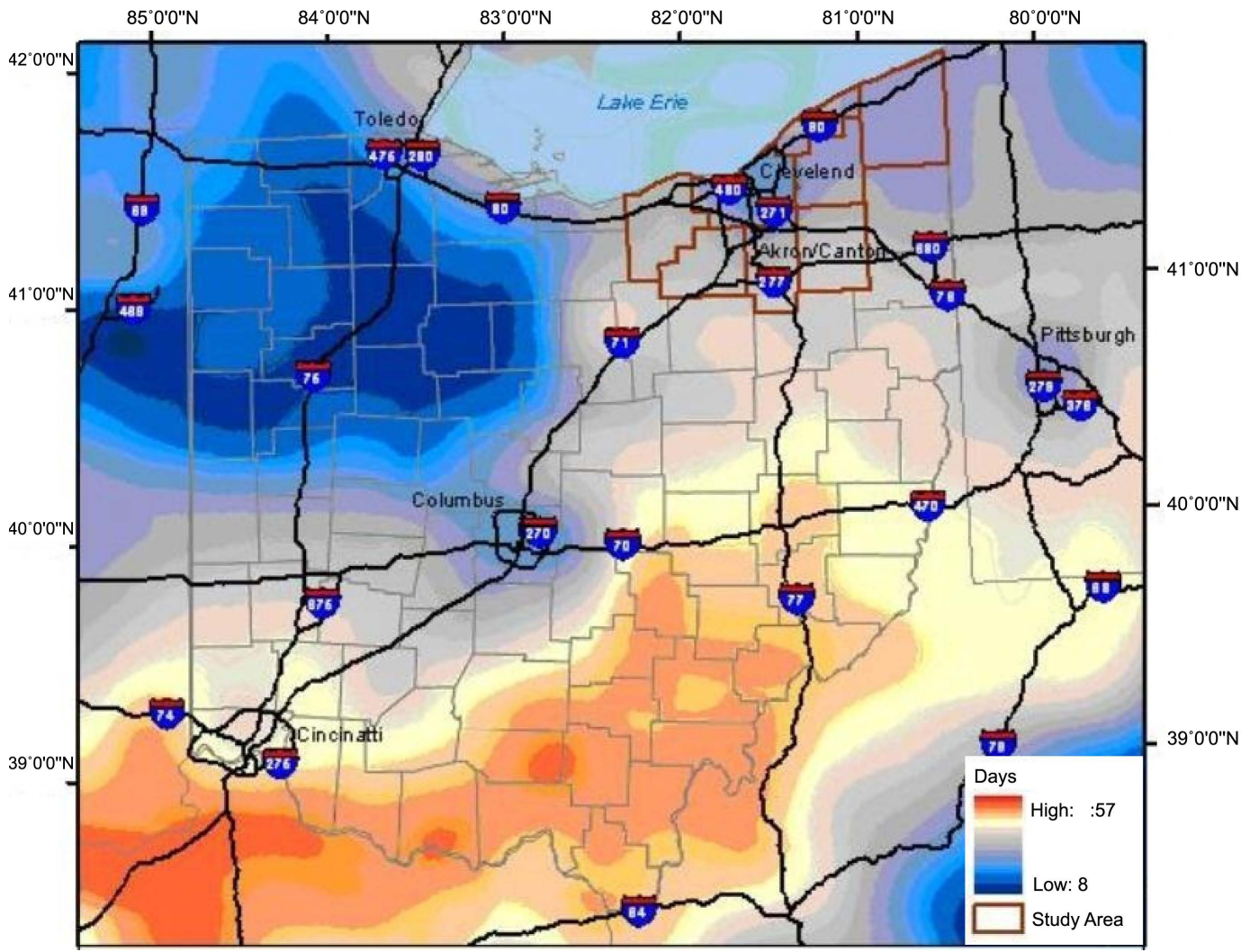

Figure 6. Spatial distribution of number of days used to calculate the RRFs in the Ohio region.

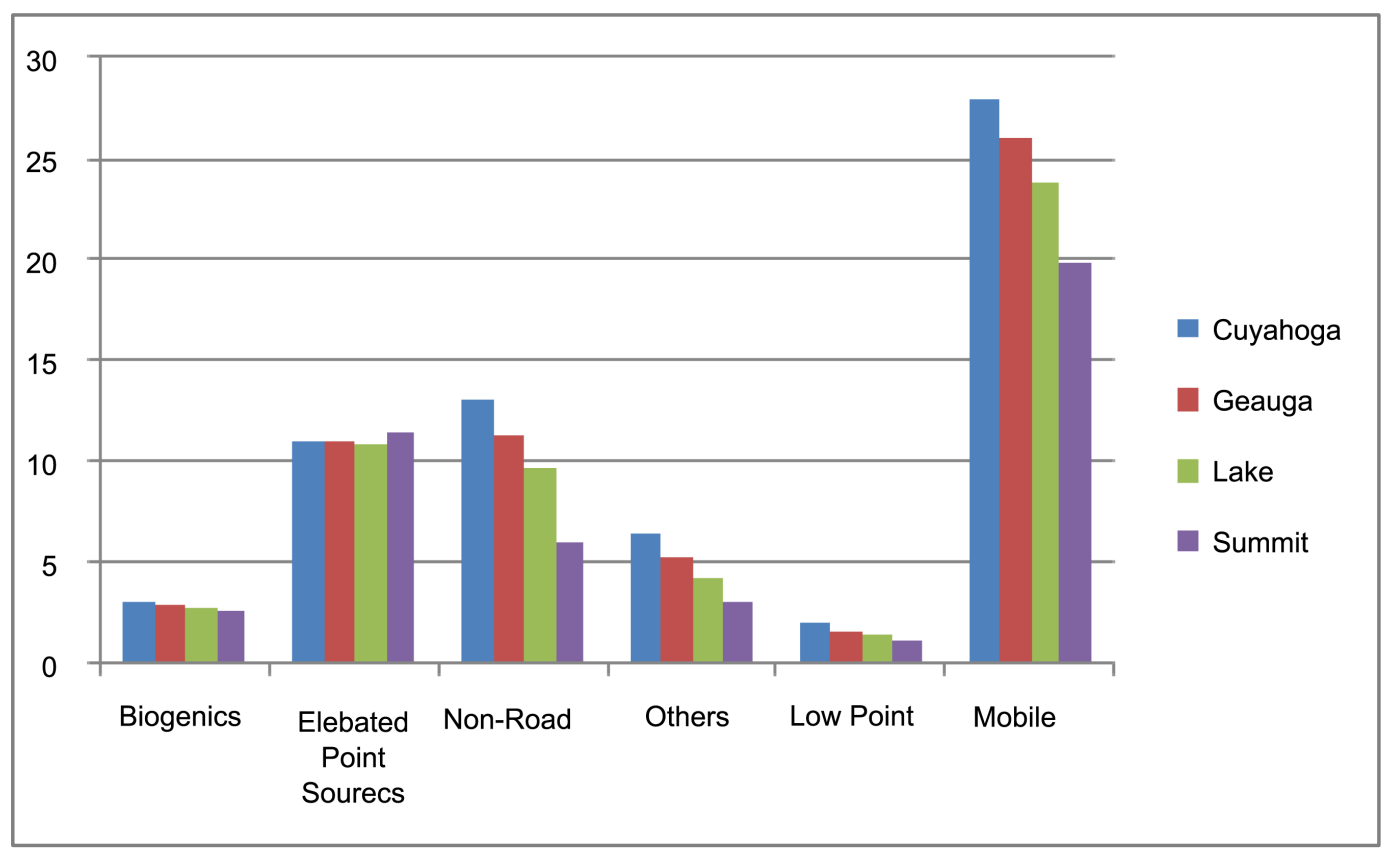

Figure 7. Impact assessment of different emission source categories in Cleveland region. 
The source apportionment generally indicates that the $\mathrm{NO}_{\mathrm{x}}$ molecules were most important in forming the next ozone molecule. This does not mean that the area was $\mathrm{NO}_{\mathrm{x}}$ saturated but that it is $\mathrm{NO}_{\mathrm{x}}$ limited. If an area is saturated in either $\mathrm{NO}_{\mathrm{x}}$ or VOC, some of the surplus can be removed and yet the same amount of ozone is formed. A substantial contributor towards $\mathrm{NO}_{\mathrm{x}}$ emissions is the Ohio region itself (more than $40 \%$ ). A significant portion of these emissions (27\%) can be attributed to trans-boundary flux (figure not shown). The surrounding states of Michigan, Kentucky, Illinois, West Virginia also contribute appreciably when the emissions from these regions are summed together. The contributions towards emissions in Cleveland by the trans-boundary fluxes and from the rest of the Ohio region are dictated mostly by meteorological processes which determine whether ozone precursor species are contained locally or are transported downwind. All monitoring sites in northeast Ohio exhibit similar patterns in the relative contributions of emissions from different source regions. Hence in Cleveland and in most areas of the Midwest the violations of 8-hour ozone standards are significantly influenced by transported pollutants.

\subsection{Impact Assessment of Additional Selected Emission Sensitive Strategies for the Region of Cleveland}

The persistent problem of non attainment of 8-hour ozone standards in the Cleveland area for the future base case 2009 warranted a deeper appraisal of the emission control strategies to be implemented in this region. Using the 2009 base case, a matrix of four separate emission sensitivity runs were conducted for the Cleveland region and the State of Ohio with the photochemical model CAMx. These specific series of initial potential emission sensitivity runs were simulated in an attempt to develop later a range of possible additional strategies to combat the ozone problem. As seen from the previous section in case of future base case scenario the mobile source emissions are the most important source contributors towards ozone. The first two emission sensitivity runs consisted primarily of assessing the impact of supplementary controls incorporated in mobile sources. The third emission sensitivity run tested the impact of additional controls integrated in the next largest contributor, the elevated point sources. The fourth scenario tested the impact of all extra controls incorporated in all source categories. The following four emission sensitivity scenarios have been briefly described below:

\section{a) Scenario 1}

The first emission sensitivity run consisted of weighing the impact of the implementation of an enhanced inspection and maintenance program, commonly referred to as E-check which is commonly one of the proposed methods to meet the stricter federal clean air standards versus the introduction of reformulated gas and low-level VOC and $\mathrm{NO}_{\mathrm{x}}$ controls for Cleveland in the emission inventory. Hence E-check was taken out of the 2009 emission inventory and reformulated gasoline and low-level emission controls incorporated in the 2009 emissions. The changes in mobile emission estimates represented below were based on Mobile6 emission estimate runs which generate tons/day totals of on-road mobile source emissions. The difference is associated with a change (difference between future base case run and the emissions sensitivity run) and considers the tons/day difference and divides it by the total on-road mobile source day and generates the \% change for $\mathrm{NO}_{\mathrm{x}}$ and $\mathrm{VOC}$ emissions for Scenario 1 and Scenario 2.

These proposed emission changes in different emission source categories over Cleveland were reflected in the 2009 emission inventory as follows:

\section{Cleveland}

- Increase of mobile source emissions of VOC by $3.70 \%$;

- Increase of mobile source emissions of $\mathrm{NO}_{\mathrm{x}}$ by $11.20 \%$;

- Decrease of low level point emissions of VOC by $9.72 \%$;

- Decreased of low level point emissions of $\mathrm{NO}_{\mathrm{x}}$ by $0.92 \%$.

\section{b) Scenario 2}

The second emission-sensitivity run assessed the additional impact of E-check along with the reformulated gasoline and low-level emission control changes included in the 2009 emissions inventory for Scenario 1 . Hence the projected emission changes in Scenario 2 are similar to Scenario 1 (including both the $\mathrm{VOC}$ and $\mathrm{NO}_{\mathrm{x}}$ controls and reformulated gasoline) with emission reductions in the mobile source category anticipated under the E-check program as shown below:

Cleveland

- Decrease of mobile source emissions VOC by $10.63 \%$; 
- Decrease of mobile source $\mathrm{NO}_{\mathrm{x}}$ emissions by $0.06 \%$;

- Decreased of low level point VOC emissions by $9.72 \%$;

- Decreased of low level point $\mathrm{NO}_{\mathrm{x}}$ emissions by $0.92 \%$.

c) Scenario 3

The third emission sensitivity run evaluated the impact of E-check versus an accelerated implementation of Clean Air Interstate Rule (CAIR) for the entire Ohio region. CAIR, which is slated for the year 2015, includes the reduction of $\mathrm{NO}_{\mathrm{x}}$ emissions from the electric-generating utility sector. The elevated point source statewide $\mathrm{NO}_{\mathrm{x}}$ change was specifically an early implementation of CAIR. For mobile source emissions the emissions sensitivity run of Scenario 1 was implemented. The expected changes in the 2009 emission inventory for different source categories were as follows:

\section{Cleveland}

- Increase of mobile source emissions of VOC by $3.70 \%$;

- Increase of mobile source emissions of $\mathrm{NO}_{\mathrm{x}}$ by $11.20 \%$;

- Decrease of low level point VOC emissions by $9.72 \%$;

- Decrease of low level point $\mathrm{NO}_{\mathrm{x}}$ emissions. Statewide

- Decrease of elevated point source emissions of $\mathrm{NO}_{\mathrm{x}}$ by $20 \%$.

d) Scenario 4

The fourth and final emission sensitivity run included the testing of the largest number of additional emission control strategies. This run integrated the statewide reductions under CAIR rule and a state wide reduction of 5\% from "other area" sources for $\mathrm{NO}_{\mathrm{x}}$ and VOC emissions to account for consumer product choices. These arise from a set of additional statewide industrial controls considered by Ohio EPA with special emphasis in the Cleveland region. In addition, these reductions also reflected E-check, reformulated gasoline, and selective reductions for low-level and upper-point emissions, as well as 'other area' emissions for the Cleveland region in particular.

Cleveland

- Decrease of mobile VOC emissions by $9.72 \%$;

- Decrease of mobile $\mathrm{NO}_{\mathrm{x}}$ emissions by $0.92 \%$;

- Decrease of VOC emissions by $15 \%$ from low level point, upper level point and "other area" emission sources;

- Decrease of $\mathrm{NO}_{\mathrm{x}}$ emissions by $15 \%$ from upper and lower point emission sources.

- Statewide

- Decrease of VOC and $\mathrm{NO}_{\mathrm{x}}$ emissions by $5 \%$ from "other area" sources;

- Decrease of elevated point sources for $\mathrm{NO}_{\mathrm{x}}$ by $20 \%$.

The RRFs were calculated for the each of the emission sensitivity runs. The future-case ozone design value at each monitoring site was calculated for each of the four emission reduction scenarios and determined by multiplying the current ozone design value from the year (2001-2003) for each monitoring site by the RRFs computed for that location. The results are displayed in Table 2 which reveals the changes in ozone design values for both Scenario 1 (without E-check), and Scenario 2 (with E-check) were moderate when compared against the 2009 base case. Even with E-check, Scenario 2 - the counties of Cuyahoga, Lake, Ashtabula, Geauga, Portage and Summit in Cleveland-still exceeded the 8-hour ozone standards. Table 2 also depicts the impact of emission controls from Scenario 3 (which implements the CAIR requirements) and Scenario 4, which also cut emissions from one of the largest sectors emitting VOCs (consumer products) in the selected region and utilized selective emission reductions in the Cleveland area. Table 2 illustrates that emission reductions in Scenario 3 did not bring the region into attainment under the 8-hour ozone standard.

For Cleveland, under Scenario 4, all the ozone monitors in the counties of Cuyahoga and Portage are in attainment. However, the monitoring sites at Lake, Ashtabula, Geauga, and Summit still exceeded the 8-hour ozone standards (Table 2). The total decrease in the 8-hour averaged ozone concentrations from the 2010 basecase scenario and Scenario 4 (which has the widest range of emission controls) is between 1.0 and $1.5 \mathrm{ppb}$. This is the maximum decrease in ozone concentrations that was obtained and was insufficient to bring the entire Cleveland region in attainment of 8-hour ozone standards.

Air pollution is currently being modeled at finer resolutions to reveal pollution "hot spots" in urban areas [29] [30] has suggested that the coarser model resolution can cause a systematic positive bias in model-simulated ozone values since the dilution of $\mathrm{NO}_{\mathrm{x}}$ emissions over relatively large grid volumes can increase ozone produc- 
tion especially in a $\mathrm{NO}_{\mathrm{x}}$-saturated region like Cleveland. The 36-km grid which is an average of nine 12-km grids, resolution used in these simulations is potentially averaging out the local reductions. The ozone changes are also potentially averaged out over the larger domain. Therefore the total impact of urban scale emission controls may be effective only on smaller grid resolutions, such as a $12-\mathrm{km}$ or a $4-\mathrm{km}$ grid resolution. The differences in RRFs between 36 and $4 \mathrm{~km}$ grid resolutions can translate to an average difference of $(1-3)$ ppb in the estimated future ozone design values [11].

The emission cuts in the individual source categories used in this study are a small percentage of total $\mathrm{NO}_{\mathrm{x}}$ or VOC emissions. For example, in the case of $\mathrm{NO}_{\mathrm{x}}$ in Scenario 4, a 15\% reduction in low-point emissions, a 5\% reduction in other categories, and a $0.92 \%$ cut in mobile emissions amounts to $1.1 \%-1.3 \%$ reduction in total merged gridded $\mathrm{NO}_{\mathrm{x}}$ emissions from the 2010 base-case emissions. The $\mathrm{NO}_{\mathrm{x}}$ emissions from industrial point sources were cut by $20 \%$; however, as explained above, the effect of the emission cuts may be averaged out in a $36-\mathrm{km}$ grid cell. In addition since the Cleveland region is VOC-sensitive the moderate $\mathrm{NO}_{\mathrm{x}}$ reductions may not have a significant impact due to the non-linear effect of ozone production 26. However it should also be kept in mind that an uncertainty of the order of 0.05 should be considered for model-predicted RRF as part of an area's attainment assessment [12]. This degree of uncertainty is inherent in the response of all current state-of-science photochemical model systems to emission reductions as they attempt to simulate complex chemistry in urban region [2].

\section{Conclusions}

This study indicated that simulating the implementation of significant control options for reducing ozone could not demonstrate attainment of the 8-hour ozone standards in the Cleveland-Akron-Lorain moderate nonattainment area. Analysis of the spatial distribution of the relative reduction factors and ozone reductions for the Ohio region demonstrated that the Cleveland area did not have significantly higher relative reduction factors or lower percent of ozone reduction than other urban areas in the Ohio region which were demonstrating attainment of the 8-hour ozone. The ozone exceedances could occur as a result of prevalent meteorological conditions combined with emission sources. A source apportionment study was also conducted in the Cleveland region using the OSAT technology in CAMx for the future base year 2009 to attempt to quantify ozone precursor transport from outside the region as well as endeavor to understand the relative contribution of different sources. It was found that downwind and trans-boundary air pollution played an important role in the air quality in Cleveland which was controlled by $\mathrm{NO}_{\mathrm{x}}$ precursor emissions.

A variety of additional emission sensitivity runs with the photochemical modeling system CAMx were conducted to assess the influence of urban and selective statewide emission controls, beyond those anticipated under the Clean Air Act to be achieved by 2009, on the averaged 8-hour daily maximum ozone concentrations in the Cleveland area. It transpired that the response of the model simulated peak 8-hour ozone to these variable emission increases or decreases was minimal in the Cleveland region on a coarse $36 \mathrm{~km}$ grid resolution. The largest change was noticeable in case of Scenario 4 (which had the largest number of additional emission controls), and the magnitude of the decrease of model simulated 8-hour ozone concentrations was between 1 and $1.5 \mathrm{ppb}$. The various reasons attributed to this minimal response were that the coarse grid resolution potentially averaged out local emission reductions, the effect of trans-boundary flux into this region and the moderate $\mathrm{NO}_{\mathrm{x}}$ emissions reductions considered were inadequate for the VOC-sensitive Cleveland region. A more detailed evaluation of the transport events from outside the state would provide valuable information in developing effective emission reduction strategies. The emission cuts should also consider more substantial emission reductions of $\mathrm{NO}_{\mathrm{x}}$, since the region is $\mathrm{NO}_{\mathrm{x}}$-saturated. However, since ozone concentrations in this region are affected by complex phenomena such as lake breeze air circulations, inversion and long-distance transport of ozone and ozone precursors, it will still be a challenging task to implement the necessary control strategies to bring the Cleveland area under 8-hr ozone attainment in context of today's stringent ozone standards and potential climate change perturbations.

\section{Acknowledgements}

The research was supported by the Ohio Environmental Protection Agency, the U.S. Environmental Protection Agency and the Northeast Ohio Areawide Coordinating Agency. The authors are indebted to Kirk Baker from U.S. Environmental Protection Agency) for his invaluable contribution. We would also like to acknowledge the 
support and technical assistance of Pam Davis and Amy Wainwright of the Northeast Ohio Areawide Coordinating Agency.

\section{References}

[1] Rao, S.T. and Zurbenko, I.G. (1994) Detecting and Tracking Changes in Ozone Air Quality. Journal of Air and Waste Management Association, 44, 1089-1092. http://dx.doi.org/10.1080/10473289.1994.10467303

[2] Chameides, W.I., Saylor, R.D. and Cowling, E.B. (1997) Ozone Pollution in the Rural United States and the New NAAQS. Science, 276, 916. http://dx.doi.org/10.1126/science.276.5314.916

[3] USEPA (2010) National Ambient Air Quality Standards Proposed Rule. Federal Register, 75, 2938-3052.

[4] USEPA (2007) Guidance on the Use of Models and Other Analyses for Demonstrating Attainment of Air Quality Goals for Ozone, $\mathrm{PM}_{2.5}$, and Regional Haze. EPA-454/B-07-002, U.S. Environmental Protection Agency: Research Triangle Park, 2007.

[5] Berman, J.D., Fann, N., Hollingsworth, J.W., Pinkerton, K.E., Rom, W. N., Szema, A.M., Breysse, P.N., White, R.H. and Curriero, F.C. (2012) Health Benefits from Large-Scale Ozone Reduction in the United States. Environmental Health Perspectives, 120, 1-30 http://dx.doi.org/10.1289/ehp.1104851

[6] Jones, J.M, Hogrefe, C., Henry, R.F., Ku, J. and Sistla, G. (2005) An Assessment of the Sensitivity and Reliability of the Relative Reduction Factor Approach in the Development of 8-Hr Ozone Attainment Plans. Journal of Air and Waste Management Association, 55, 13-19. http://dx.doi.org/10.1080/10473289.2005.10464601

[7] Houyoux, M.R., Vucovich, J.M., Coats Jr., C.J., Wheeler, N.J.M. and Kasibhatla, P. (2000) Emission Inventory Development and Processing for the Seasonal Model for Regional Air Quality (SMRAQ) Project. Journal of Geophysical Research, 105, 9079-9090. http://dx.doi.org/10.1029/1999JD900975

[8] Kasibhatla, P. and Chameides, W.L. (2000) Seasonal Modeling of Regional Ozone Pollution in the Eastern United States. Geophysical Research Letters, 27, 1415-1418. http://dx.doi.org/10.1029/1999GL011147

[9] Tesche, T.W., McNally, D.E., Loomis, C.F., Morris, R.E. and Mansell, G.E. (2003) Air Quality Modeling Analysis for the San Juan Early Action Ozone Compact, Ozone Modeling Protocol. Alpine Geophysics, Ft. Wright Kentucky and ENVIRON International Corporation, Novato.

[10] USEPA (1999) Draft Guidance on the Use of Models and Other Analyses in Attainment Demonstrations for the 8Hour Ozone NAAQS. EPA-454/R-99-004, Environmental Protection Agency, Research Triangle Park, 27711.

[11] Arunachalam, S., Holland, A., Do, B. and Abraczinskas, M. (2006) A Quantitative Assessment of Influence of Grid Resolution on Predictions of Future-Year Air Quality in North Carolina, USA. Atmospheric Environment, 40, 50105026. http://dx.doi.org/10.1016/j.atmosenv.2006.01.024

[12] Sistla, G., Hogrefe, C., Hao, W., Ku, J.-Y., Zalewsky, E., Henry, R.F. and Civerolo, K. (2004) An Operational Assessment of the Application of the Relative Reduction Factors (RRF) in Demonstration of Attainment of the 8-hr Ozone National Ambient Air Quality Standard (NAAQS). Journal of Air and Waste Management Association, 54, 950959. http://dx.doi.org/10.1080/10473289.2004.10470964

[13] Biswas, J., John, K. and Farooqui, Z. (2009) Impact Assessment of Global Temperature Perturbations on Urban and Regional Ozone Levels in South Texas. In: Singh, G.P. and Oh, J.H., Eds., Advances in Geosciences, Volume 10: Atmospheric Science (AS), World Scientific, Singapore, 197-211.

[14] ENVIRON (2003) User's Guide to the Comprehensive Air Quality Model with Extensions (CAMx). Version 4.00, January 2003. http://www.camx.com

[15] ENVIRON International Corporation (2010) User's Guide Emissions Processor Version 3.20 (EPS3). ENVIRON International Corporation, Novato, 184.

[16] Grell, G.A., Dudhia, J. and Stauffer, D. (1994) A Description of the Fifth-Generation State/NCAR Mesoscale Model (MM5). NCAR Technical Note, TN-398 + STR, National Center for Atmospheric Research, Boulder, 138.

[17] Baker, K.R. (2005) CAMx4 Model Performance for Ozone in the Upper Midwest over the Summers of 2001, 2002 and 2003. Proceedings of the 98th Annual Meeting of the Air and Waste Management Association, Minneapolis, 21-24 June 2005.

[18] NRC (1991) Rethinking the Ozone Problem in Urban and Regional Air Pollution. National Academy Press, Washington DC, $524 \mathrm{p}$.

[19] Tesche, T., Georgopoulos, W.P., Seinfield, J.H., Lurman, F. and Roth, P.M. (1990) Improvements in Procedures for Evaluating Photochemical Models. Rep. A832-103, California Air Resources Board, Sacramento, 200 p.

[20] Fox, D.G. (1981) Judging Air Quality Model Performance. Bulletin of the American Meteorological Society, 62, 599609. http://dx.doi.org/10.1175/1520-0477(1981)062<0599:JAQMP>2.0.CO;2 
[21] Sistla, G., Zhou, N., Hao, W., Ku, J.Y. and Rao, S.T. (1996) Effects of Uncertainties in Meteorological Inputs of Urban Airshed Model Predictions and Ozone Control Strategies. Atmospheric Environment, 30, 2011-2025. http://dx.doi.org/10.1016/1352-2310(95)00268-5

[22] USEPA (1991) Guideline for Regulatory Applications for Regulatory Applications of the Urban Airshed Model. EPA-450/4-91/013, Environmental Protection Agency, Research Triangle Park.

[23] USEPA (2007) Guidance on the Use of Models and Other Analyses for Demonstrating Attainment of Air Quality Goals for Ozone, PM2.5, and Regional Haze. EPA-454/B-07-002, U.S. Environmental Protection Agency, Research Triangle Park.

[24] NRC (1999) Ozone-Forming Potential of Reformulated Gasoline. National Academy Press, Washington DC, 212.

[25] Sillman, S. (1999) The Relation between Ozone, NOx and Hydrocarbons in Urban and Rural Polluted Environments. Atmospheric Environment, 33, 1821-1845. http://dx.doi.org/10.1016/S1352-2310(98)00345-8

[26] Pagnotti, V. (1987) A Meso-Meteorological Feature Associated with High Ozone Concentrations in the Northeastern United States. Journal of Air Pollution Control Association, 37, 720-732. http://dx.doi.org/10.1080/08940630.1987.10466258

[27] Morris, R.E., Wilson, G.M., Shepard, S.B. and Lee, K. (1997) Ozone Source Apportionment Modeling Using the 1991 OTAG Episode for the Northeast Corridor and Lake Michigan Regions. ENVIRON International Corporation Draft Report to Cinergy Corporation, Plainfield, IN.

[28] Dunker, A., Yarwood, G., Ortmann, J. and Wilson, G. (2002) Comparison of Source Apportionment and Source Sensitivity of Ozone in a Three-Dimensional Air Quality Model. Environmental Science and Technology, 36, 2953-2964. http://dx.doi.org/10.1021/es011418f

[29] Sillman, S., Logan, J.A. and Wofsky, S.C. (1990) A Regional Scale Model for Ozone in the United States with Subgrid Representation of Urban and Power Plant Plumes. Journal of Geophysical Research, 95, 5731-5748. http://dx.doi.org/10.1029/JD095iD05p05731

[30] Ching, J., Dupont, S., Herwehe, J., Otte, S.T., Lacser, A., Byun, D. and Tang, R. (2004) Air Quality Modeling at Coarse-to-Fine-Scales in Urban Areas. Proceedings of the Sixth Conference on Atmospheric Chemistry: Air Quality in Megacities, Seattle, 11-15 January 2004, American Meteorological Society, ATDD Contribution File \# 04-16. 